\title{
A guide to delineate the logic of neurovascular signaling in the brain
}

\section{David Kleinfeld 1,2,3*, Pablo Blinder', Patrick J. Drew' ${ }^{1}$, Jonathan D. Driscoll' , Arnaud Muller', Philbert S. Tsai' and Andy Y. Shih ${ }^{1}$}

\author{
Department of Physics, University of California San Diego, La Jolla, CA, USA \\ 2 Section of Neurobiology, University of California San Diego, La Jolla, CA, USA \\ ${ }^{3}$ Center for Neural Circuits and Behavior, University of California San Diego, La Jolla, CA, USA
}

\section{Edited by:}

Anna Devor, University of California

San Diego, USA

\section{Reviewed by:}

Christopher I. Moore, Massachusetts

Institute of Technology, USA

Samuel S.-HWang, Princeton

University, USA

\section{*Correspondence.}

David Kleinfeld, Department of

Physics, University of California, 9500

Gilman Drive, La Jolla, CA 92093-0374,

USA.

e-mail:dk@physics.ucsd.edu
The neurovascular system may be viewed as a distributed nervous system within the brain. It transforms local neuronal activity into a change in the tone of smooth muscle that lines the walls of arterioles and microvessels. We review the current state of neurovascular coupling, with an emphasis on signaling molecules that convey information from neurons to neighboring vessels. At the level of neocortex, this coupling is mediated by: (i) a likely direct interaction with inhibitory neurons, (ii) indirect interaction, via astrocytes, with excitatory neurons, and (iii) fiber tracts from subcortical layers. Substantial evidence shows that control involves competition between signals that promote vasoconstriction versus vasodilation. Consistent with this picture is evidence that, under certain circumstances, increased neuronal activity can lead to vasoconstriction rather than vasodilation. This confounds naïve interpretations of functional brain images. We discuss experimental approaches to detect signaling molecules in vivo with the goal of formulating an empirical basis for the observed logic of neurovascular control.
Blood is a vital and limited resource in the brain. All aspects of neuronal and non-neuronal activity require a supply of oxygen and glucose - a need that constantly evolves with changes in brain activity (Fox and Raichle, 1986; Leybaert, 2005). How is the distribution of blood controlled relative to these changing needs? More basically, what are the signals that different classes of cells use to communicate changes in their metabolic load? How are these signals integrated to change the flow in the blood vessels that intercalate cortical neurons and glia (Figure 1)?

An understanding of neurovascular signaling bears directly on the limit to cortical function and, more generally, on resource management by the central nervous system. From a clinical perspective, understanding the relation of neuronal activity to changes in blood oxygen and flow is an essential step toward addressing the role of vascular dysfunction and disease in dementia (Paulson et al., 1990; Kövari et al., 2007). From the perspective of cognitive science, a quantitative understanding of neurovascular signaling is crucial for the interpretation of functional brain images (LeDoux et al., 1983 ) - especially those obtained with blood oxygenation level dependent functional magnetic resonance imaging (BOLD fMRI). Magnetic resonance imaging and other macroscopic diagnostic techniques have provided a "window" into the brain from which modulation of macroscopic blood by neuronal activity may be assessed (Belliveau et al., 1991; Ogawa et al., 1992). These techniques are likely to evolve into essential tools for judging cognitive capabilities in a clinical setting and may be critical for the early identification and hopefully containment of dementia.

We view neurovascular control in terms of the net action of a tractable number of signaling molecules that arrive via one global and two local pathways (Figure 2). All of these function in a push-pull manner, i.e., one set of signals induces vasodilation through relaxation of arteriole smooth muscle, while a second set induces vasoconstriction (Cauli et al., 2004). The first local pathway involves local inhibitory interneurons that act directly on smooth muscle. Different subclasses of interneurons co-release different transmitters that act to either dilate vessels, including nitric oxide (NO) and vasoactive intestinal peptide (VIP), or to constrict vessels, including the neuropeptides somatostatin (SOM) and neuropeptide Y (NPY). In some cases the same interneuron can cause both effects; e.g., some SOM-expressing cells further express nitric oxide synthetase (Kawaguchi, 2001). Additional evidence for a role of interneurons in the modulation of blood flow comes from an increase in flow concurrent with $\gamma$-band oscillations in inhibitory networks (Niessing et al., 2005). Increases in flow correlate with such global rhythms. It is thus natural to hypothesize that the competition between dilation and constriction depends on the relative activation of different inhibitory networks (Gibson et al., 1999); this hypothesis may be tested with cell-specific markers of neuronal activity.

The second local pathway for the control of blood flow originates with excitatory neurons and acts via astrocytes (Filosa et al., 2004; Iadecola and Nedergaard, 2007). Volume conduction of the excitatory transmitter glutamate can cause an increase in intracellular $\mathrm{Ca}^{2+}$ in astrocytes, which in turn initiates the conversion of arachidonic acid to the dilators prostaglandin $\mathrm{E}\left(\mathrm{PG}_{\mathrm{E}}\right)$ and epoxyeicosatrienoic acid (EET) or the constrictor 20-hydroxyeicosatetraenoic acid (20-HETE). Recent work shows that the competition between dilation and constriction depends on the partial pressure of oxygen $\left(\mathrm{pO}_{2}\right)$ (Gordon et al., 2008); dilation dominates at low $\mathrm{pO}_{2}$.

Lastly, global pathways involve the vasodilator acetylcholine (ACh) and the constrictor serotonin (5HT), released from their respective subcortical nuclei, i.e., nucleus basalis magnocellularis 


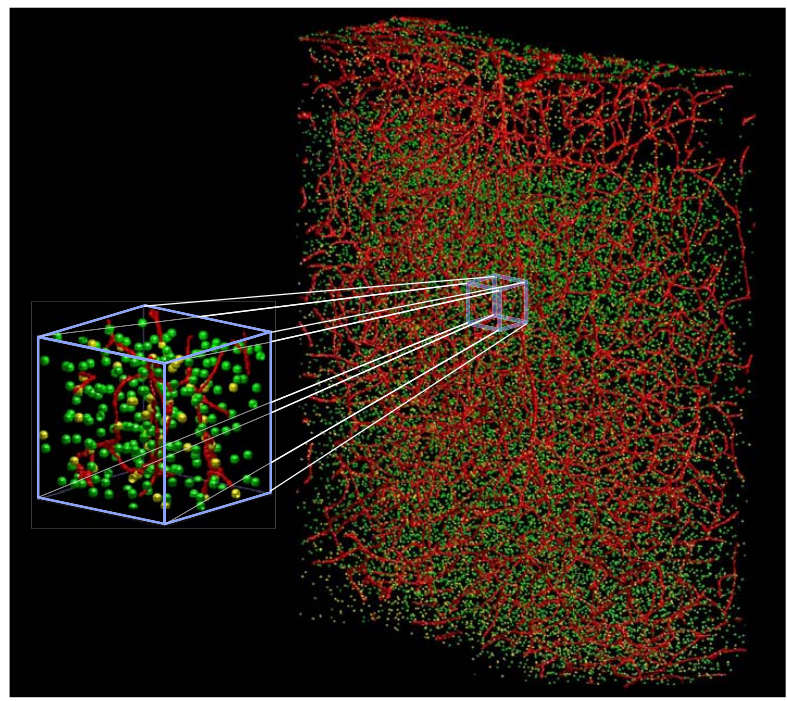

FIGURE 1 |Three dimensional vectorized reconstruction of all of the cell soma and blood vessels in a slab of mouse cerebral cortex. Features in the raw data are analyzed and transformed into a digital map that represents them as cylinders and spheres with vector coordinates and associated radii. The vascular network is in red, the neuronal nuclei are in green, and non-neuronal nuclei are in yellow. The total volume is a $600-\mu \mathrm{m} \times 900-\mu \mathrm{m} \times 250-\mu \mathrm{m}$. Derived from Tsai et al. (2003, 2009)

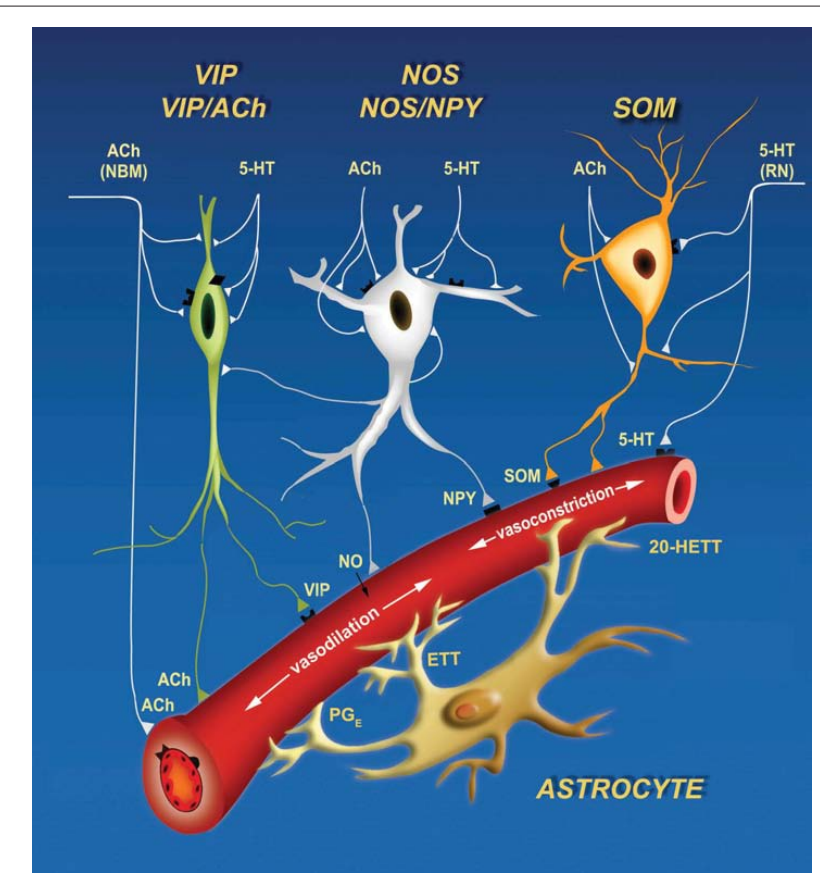

FIGURE 2 | Cartoon of three signaling pathways, two local and one global, that can both constrict and dilate the arteriole vasculature. Inhibitory interneurons can drive dilation via nitric oxide (NO), catalyzed by nitric oxide synthetase (NOS), and vasoactive intestinal peptide (VIP), and drive constriction via somatostatin (SOM) and neuropeptide Y (NPY). Astrocytes can dilate via protoglandin $E\left(P_{E}\right)$ and epoxyeicosatrienoic acid (EET) and constrict via 20-Hydroxyeicosatetraenoic acid (20-HETE). Lastly, extrinsic input of acetylcholine (ACh) will dilate while serotonin $(5 \mathrm{HT})$ will constrict. Derived from Cauli et al. (2004). and the dorsal raphe nucleus (Hamel, 2004, 2006). An additional neural pathway for the modulation of cortical blood flow occurs via the rostral ventrolateral medulla (RVLM; Golanov and Reis, 1996), whose projections to cortex are relayed by the interlaminar thalamic nucleus. Neurons in the RVLM are sensitive to oxygen levels. Their activation causes bilateral increase in cortical blood flow via thalamic intermediates. This raises the possibility that changes in cortical blood flow and activity are slaved to fluctuations in breathing and blood oxygenation (Wise et al., 2004; Shmueli et al., 2007; Drew et al., 2008). Blood flow is further driven by cortical state (Jones et al., 2008); this mode of control may well lie in changes in the patterns of activation of excitatory cells and subpopulations of inhibitory cells (Figure 2) that may involve modulatory control via Ach and 5HT pathways, as well as noradrenergic inputs (NA) from locus coeruleus (Cohen et al., 1997).

\section{POTENTIAL FOCUS OF AN EXPERIMENTAL PROGRAM}

We consider competition among vasoactive pathway that predominantly effect parenchymal microvessels. We hypothesize that microvascular tone may be defined as a function of the local concentration of specific signaling molecules, such as EET, 20-HETE, $\mathrm{NO}, \mathrm{NPY}, \mathrm{PG}_{\mathrm{E}}, \mathrm{SOM}$, and VIP. The driving term is neuronal activity, which may be a one-to-one function of the neuronal stimulus for primary sensory areas. Formally, we seek a relation of the form

Smooth muscle tension

$$
\equiv \mathrm{f}\left(\begin{array}{c}
\mathrm{SOM}^{+} \text {inhi bitory interneuron activation } \\
\mathrm{VIP}^{+} \text {inhi bitory interneuron activation } \\
\vdots \\
\text { Astrocyteactivation }=\mathrm{f}(\text { excitatory cell activation }) \\
\text { Extracortical and endothelial contributions } \\
{\left[\mathrm{O}_{2}\right]_{\text {tissue }}}
\end{array}\right)
$$

and

Vascular output $\equiv \mathrm{f}\left(\begin{array}{c}\text { Smooth muscle tension } \\ \vdots \\ \text { V ascular architecture }\end{array}\right)$

where the functionalities, denoted $f$, are yet to be determined. Nonetheless, this general formalism emphasizes the need to study muscle tension on a cell type-by-type or transmitter-by-transmitter basis. It further reinforces the need to map the geometry of the vasculature (Figure 1) and the location of neuronal control regions (Figure 2).

The greatest uncertainty in the hypothesis that the control of cortical blood flow depends on the balance of neurotransmitters that lead to vasoconstriction versus dilation is that much of our understanding of signaling comes from experiments with brain slice preparations. Not only is vascular pressurization absent, but responses take place on tens of seconds (Cauli et al., 2004; Gordon et al., 2008), while the vasculature responds to changes in neuronal activity on the 0.5-s time-scale in vivo. It remains an open issue if signaling is faster in vivo, although such long times are observed when astrocytic $\mathrm{Ca}^{2+}$ levels are directly excited in vivo (Wang et al., 2006; Figure 3). 
A
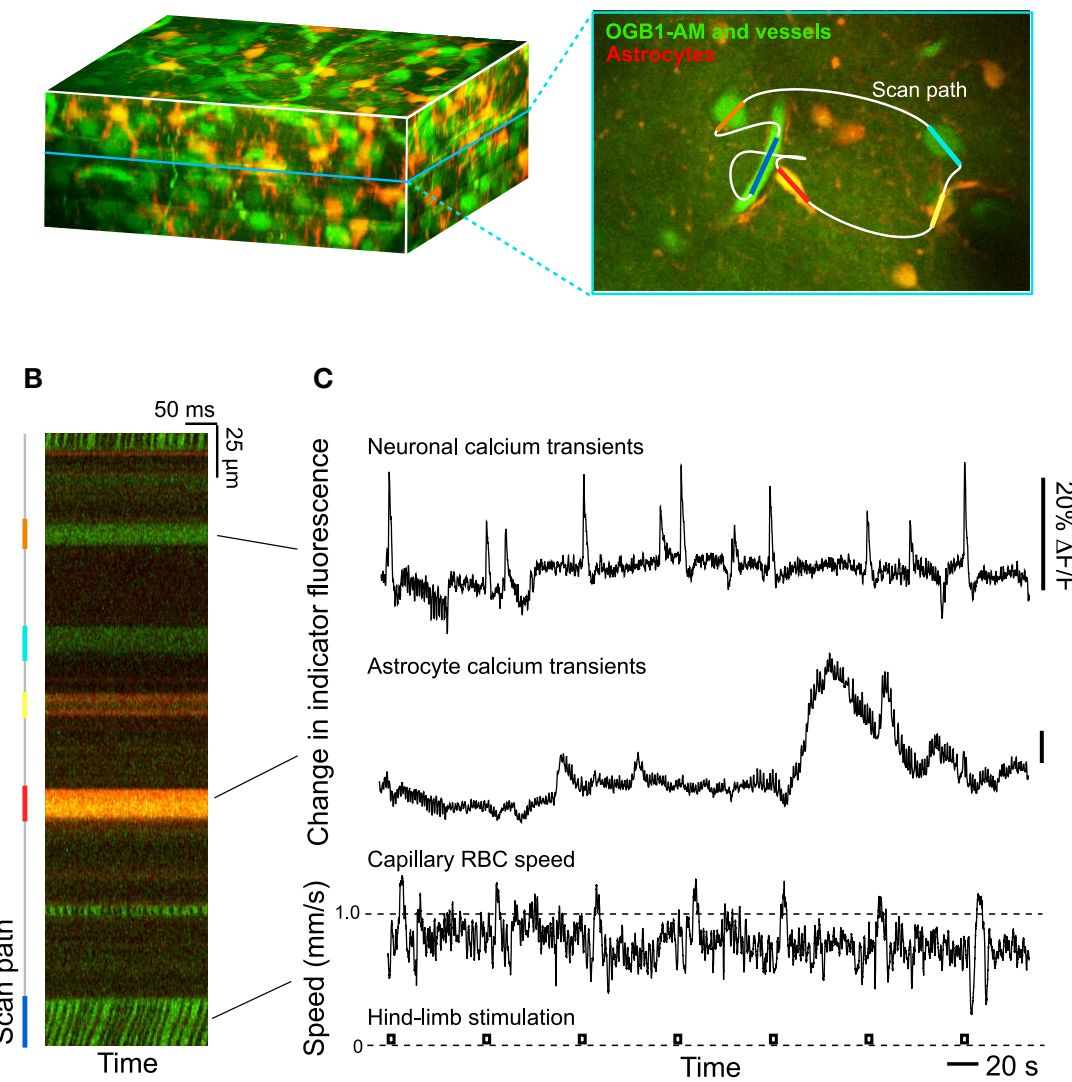

FIGURE 3 |Two-photon laser scanning microscopy with arbitrary scan pathways to record from functionally labeled cells and vessels. (A) Neurons and glia are labeled with the $\mathrm{Ca}^{2+}$ reporter Oregon Green BAPTA-1 AM and glia have sulforhodamine 101 as an additional label. Blood plasma is stained with fluorescein so that blood cell motion is measured. (B) Intensity along the scan path records $\mathrm{Ca}^{2+}$ signals and blood cell movement. (C) Traces of functional changes in intracellular $\mathrm{Ca}^{2+}$ and flood flow; note flow changes concurrent with stimulation. Algorithms from Helmchen and Kleinfeld (2008), Drew et al. (2010), Driscoll et al. (2011).
A first approach to define the inputs and output to a model of neurovascular coupling is to measure the activity of identified cell types concurrent with blood flow in a neighboring microvessel. The activity of neurons and glia in cortex may be established by measuring their internal calcium levels with optical contrast agents (Garaschuk et al., 2006; Figure 3) and in vivo two-photon laser scanning microscopy (TPLSM; Svoboda et al., 1997; Figure 3). Similarly, both the speed of blood cells and vascular tone may be concurrently established with two-photon microscopy (Helmchen and Kleinfeld, 2008; Figure 3). The clarity of these measurements depends on the ability to record from specific cell types and the specificity of co-release of different neuropeptides by interneurons. This implies the need to use transgenic animals that either express a functional indicator in specific cell types or, as a more general approach, to use mice that express Cre recombinase in specific cell types (Luo et al., 2008; Bernard et al., 2009; Table 1). Cre recombinase drives the labeling of these cells types by crossing these mouse lines with fluorescent reporter mice (Madisen et al., 2010), in which a member of the fluorescent protein (FP) family (Tsien, 1998; Shaner et al., 2004) and/or a genetically encoded functional indicator is coded between lox-sites (Wallace et al., 2008; Table 2); Cre recombinase activates sequences between these sites (Mallo,
2006). A complementary and common method is to infect cells that express Cre recombinase with a virus whose genetic material is modified to code a fluorescent indicator between lox-sites (Table 2). As a technical issue, a construct with double lox-sites improves specificity of Cre recombinase targeting strategies (Atasoy et al., 2008).

A second, albeit related approach is to manipulate the output of the neurons and astrocytes that release signaling factors and measure the volume concentration of signaling molecules, particularly under conditions of changing vascular dilation versus constriction. The activity of neurons and glia may be manipulated with photoexcitation of caged molecules, with ectopic expression of chemical receptors modified to have unnatural affinities to a specific drug (Alexander et al., 2009), with ectopic expression of receptors with native binding sites (Arenkiel et al., 2008), and with optogenetic agents that are targeted to specific cell types (Cardin et al., 2009, 2010; Sohal et al., 2009). The latter strategy includes the use of channelrhodopsin (ChR2) to depolarize cells (Boyden et al., 2005; Arenkiel et al., 2007; Gradinaru et al., 2009) and halorhodopsin (NpHR; Zhang et al., 2007) or archaerhodopsin-3 (Arch; Chow et al., 2010) to inactivate cells. Other agents act directly on specific G-protein coupled pathways (Airan et al., 2009). All of these agents are typically delivered 
by viral injection in combination with Cre recombinase labeled animals, as described above (Tables 1 and 2). A complementary strategy is the use of short hairpin RNA (shRNAs) to silence specific cell signaling pathways (Table 3 ).

The presence of multiple sources for the different signaling molecules suggests the additional need to measure receptor activation by these molecules directly. Receptor activation via the volume conduction of vasoactive signaling molecules may be observed with new cell-based indicators, CNiFERs, that can be made sensitive to any molecule that has a G-coupled protein receptor (Figures 4A,B). In a first realization with ACh sensing as the task, HEK cells were transfected with the muscarinic (M1) $\mathrm{G}_{\mathrm{q}}$-protein receptor along with the $\left[\mathrm{Ca}^{2+}\right]_{\text {int }}$ reporter TN-XXL (Heim and Griesbeck, 2004). These show a strong response to the release of endogenous ACh

Table 1 | Mice that express fluorescent proteins or Cre recombinase in cell-types relevant to neurovascular regulation.

\begin{tabular}{|c|c|c|c|c|}
\hline Promotor & Expression & Goal & Jax number & References \\
\hline hGFAP & eGFP & Visualization of cortical astrocytes & & Nolte et al. (2001) \\
\hline GAD67 & GFP & $\begin{array}{l}\text { Visualization of parvalbumin, calretinin, } \\
\text { or somatostatin-positive interneurons }\end{array}$ & $\begin{array}{l}003718,007677 \\
006334\end{array}$ & $\begin{array}{l}\text { Oliva Jr. et al. (2000), Tamamaki et al. (2003), } \\
\text { Chattopadhyaya et al. (2004), Ma et al. (2006) }\end{array}$ \\
\hline Camk2a & tdTomato (a red FP) & $\begin{array}{l}\text { Visualization of cortical excitatory } \\
\text { neurons }\end{array}$ & & Madisen et al. (2010) \\
\hline Camk2a & Cre recombinase & $\begin{array}{l}\text { Gene targeting to cortical excitatory } \\
\text { neurons }\end{array}$ & 005359 & Tsien et al. (1996) \\
\hline hGFAP & Cre recombinase & Gene targeting to cortical astrocytes & 004600 & Brenner et al. (1994), Zhuo et al. (2001) \\
\hline Parvalbumin & Cre recombinase & $\begin{array}{l}\text { Gene targeting of parvalbumin-positive } \\
\text { cortical interneurons }\end{array}$ & 008069 & Wulff et al. (2008) \\
\hline $\begin{array}{l}\text { Smooth muscle } \\
\text { myosin heavy chain }\end{array}$ & $\begin{array}{l}\text { Cre recombinase } \\
\text { and GFP }\end{array}$ & $\begin{array}{l}\text { Gene targeting and visualization of pial } \\
\text { vascular smooth muscle }\end{array}$ & 007742 & Xin et al. $(2002 a, b)$ \\
\hline
\end{tabular}

Table 2 | Viral expression cassettes for in vivo manipulation and detection of astrocyte and interneuronal signaling.

\begin{tabular}{|c|c|c|c|}
\hline Protein expressed & Goal & Targeting strategies & References \\
\hline Channelrhodopsin 2 & Light-mediated cell depolarization & & $\begin{array}{l}\text { Arenkiel et al. (2007), Gradinaru } \\
\text { et al. (2009) }\end{array}$ \\
\hline Halorhodopsin & Light-mediated cell hyperpolarization & (i) Cre-lox & Zhang et al. (2007), Chow et al. (2010) \\
\hline Archaerhodopsin-3 & & (ii) Cell type - specific promoters & \\
\hline $\begin{array}{l}\text { hM3Dq (G-coupled protein } \\
\text { receptor for cell activation) }\end{array}$ & $\begin{array}{l}\text { Drug-based (clozapine-N-oxide) } \\
\text { regulation of activity }\end{array}$ & (iii) Cell type - trophic viruses & Alexander et al. (2009) \\
\hline TRPV1 & $\begin{array}{l}\text { Ligand-based (capsaicin) regulation } \\
\text { of activity }\end{array}$ & & Arenkiel et al. (2008) \\
\hline $\begin{array}{l}\text { Tn-XXL or GCaMP3 (Fluorescent } \\
\text { protein based } \mathrm{Ca}^{2+} \text { sensors) }\end{array}$ & $\begin{array}{l}\text { Cell-specific detection of intracellular } \\
\text { calcium increases }\end{array}$ & & Mank et al. (2008), Tian et al. (2009) \\
\hline
\end{tabular}

Table 3 | Viral expression cassettes for in vivo genetic manipulation of astrocyte and interneuronal signaling.

\begin{tabular}{|c|c|c|c|}
\hline shRNA target & Pathway & Targeting strategies & References \\
\hline mGluR & Astrocyte glutamate signaling pathway & & Zonta et al. (2003) \\
\hline $\begin{array}{l}\text { phospholipase } A_{2} \text {, cyclo- } \\
\text { oxygenase- } 1 \text {, or cytochrome p450 }\end{array}$ & Astrocyte arachidonic acid metabolism & & Zonta et al. (2003), Mulligan and MacVicar (2004) \\
\hline $\begin{array}{l}\mathrm{Ca}^{2+} \text { sensitive large conductance BK } \\
\text { channels }\end{array}$ & Astrocytic potassium release & & $\begin{array}{l}\text { Filosa et al. (2006), Weaver et al. (2006), Girouard } \\
\text { et al. (2010) }\end{array}$ \\
\hline VIP or vascular receptor VPAC1 & Interneuron VIP release & Cre-lox & Fahrenkrug et al. (2000), Cauli et al. (2004) \\
\hline NOS & Interneuron NO release & & Cauli et al. (2004), Enager et al. (2008) \\
\hline SOM or vascular receptor SSTR & Interneuron SOM release & & $\begin{array}{l}\text { Cauli et al. (2004), Enager et al. (2008), } \\
\text { Kocharyan et al. (2008) }\end{array}$ \\
\hline NPY or vascular receptor NPY-Y1 & Interneuron NPY release & & Cauli et al. (2004) \\
\hline
\end{tabular}




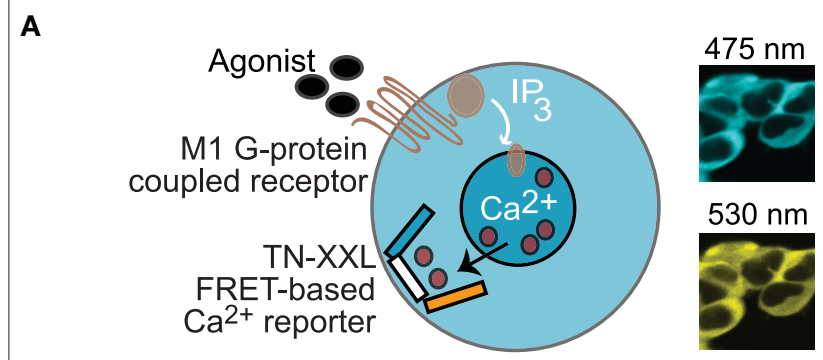

B
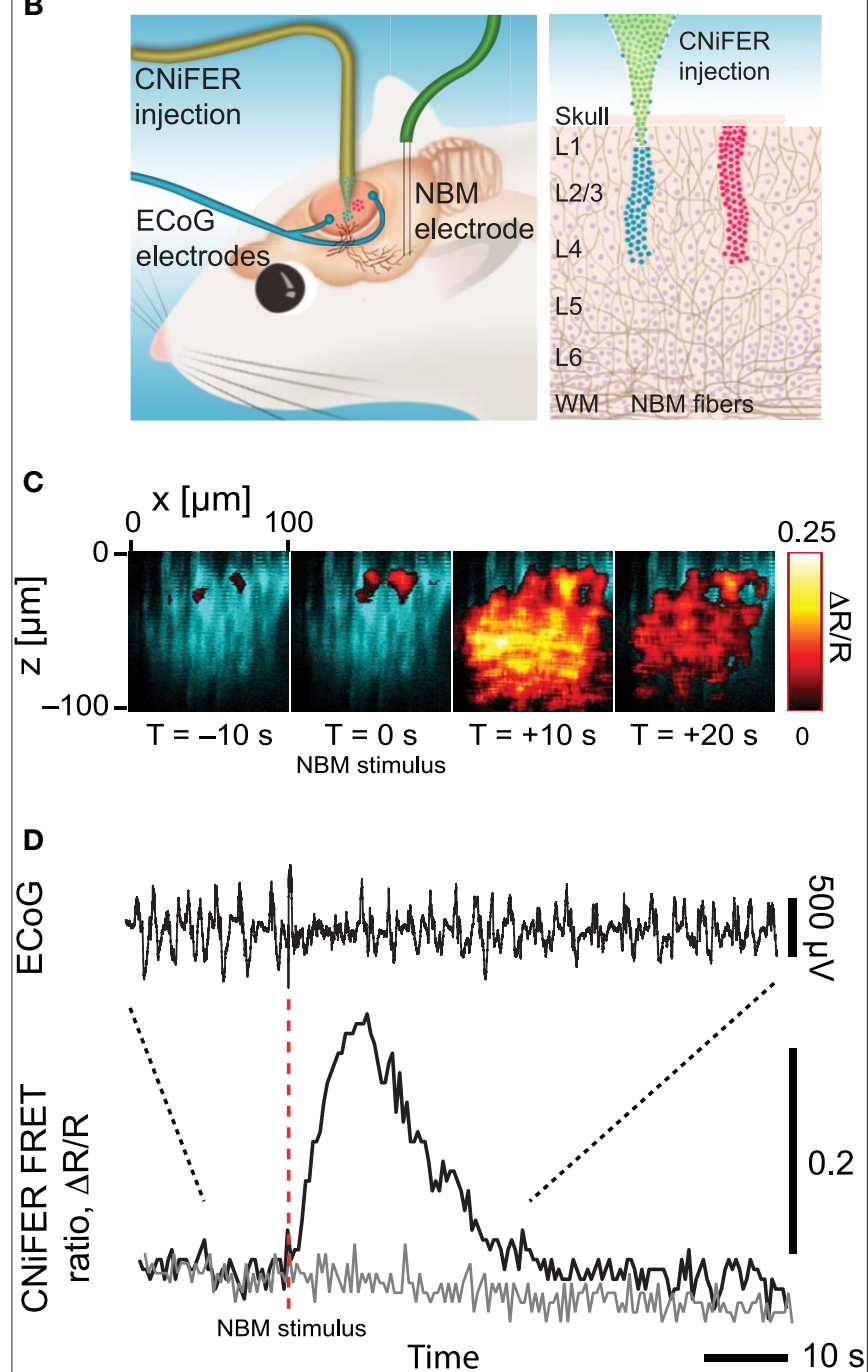

FIGURE 4 | Overview of CNiFER methodology. (A) Schematic of the cell-based sensors with a Gq family, G-protein coupled receptor for acetylcholine and the TN-XXL genetically expressible calcium reporter. (B). Cartoon of the injection of CNiFERs and the placement of microelectrodes in rat frontal cortex. (C) In vivo response of M1-CNiFERs to cholinergic input after electrical activation of nucleus basalis (NBM). The X-Z scan was obtained with TPLSM through the depth of cortex before and after activation of cholinergic neurons in NBM. (D) Time dependence of the M1-CNiFER response, together with control data from CNiFERs without the M1 receptor, and the electrocorticogram (ECoG). The decrease in amplitude of the ECoG after stimulation, as expected for cholinergic activation of cortex. Adapted from Nguyen et al. (2010).
(Figures 4C,D). CNiFER technology may be extended, by the use of $\mathrm{G}_{\mathrm{i} / \mathrm{o}}$ - and $\mathrm{G}_{\mathrm{s}}$-protein receptors and chimeric $\mathrm{G} \alpha$-q proteins (Coward et al., 1999), to sense neuropeptides such as VIP and SOM.

In toto, the combination of many in vivo tools, including electrophysiology, in vivo two-photon imaging, intracellular ion measurements (Figure 3), neurotransmitter receptor activation measurements (Figure 4), microdialysis measurements, single vessel blood flow measurements (Figure 3) as well as direct measurement of the activation of smooth muscle (Figure 5), and measurement of tissue oxygen levels (Sakadzic' et al., 2010), can allow one to assess the influence of single neurons and networks of neurons on vascular control. These can be further supported by optical and chemical activation of specific cell types, as illustrated by the optical activation of astrocytes to increase blood flow in neighboring capillaries (Figure 6) in a manner similar to that seen with caged compounds (Takano et al., 2006). Lastly, automated reconstruction techniques allow one to map local architectonics (Figure 1). In all such endeavors, it important to realize that one may conceive new

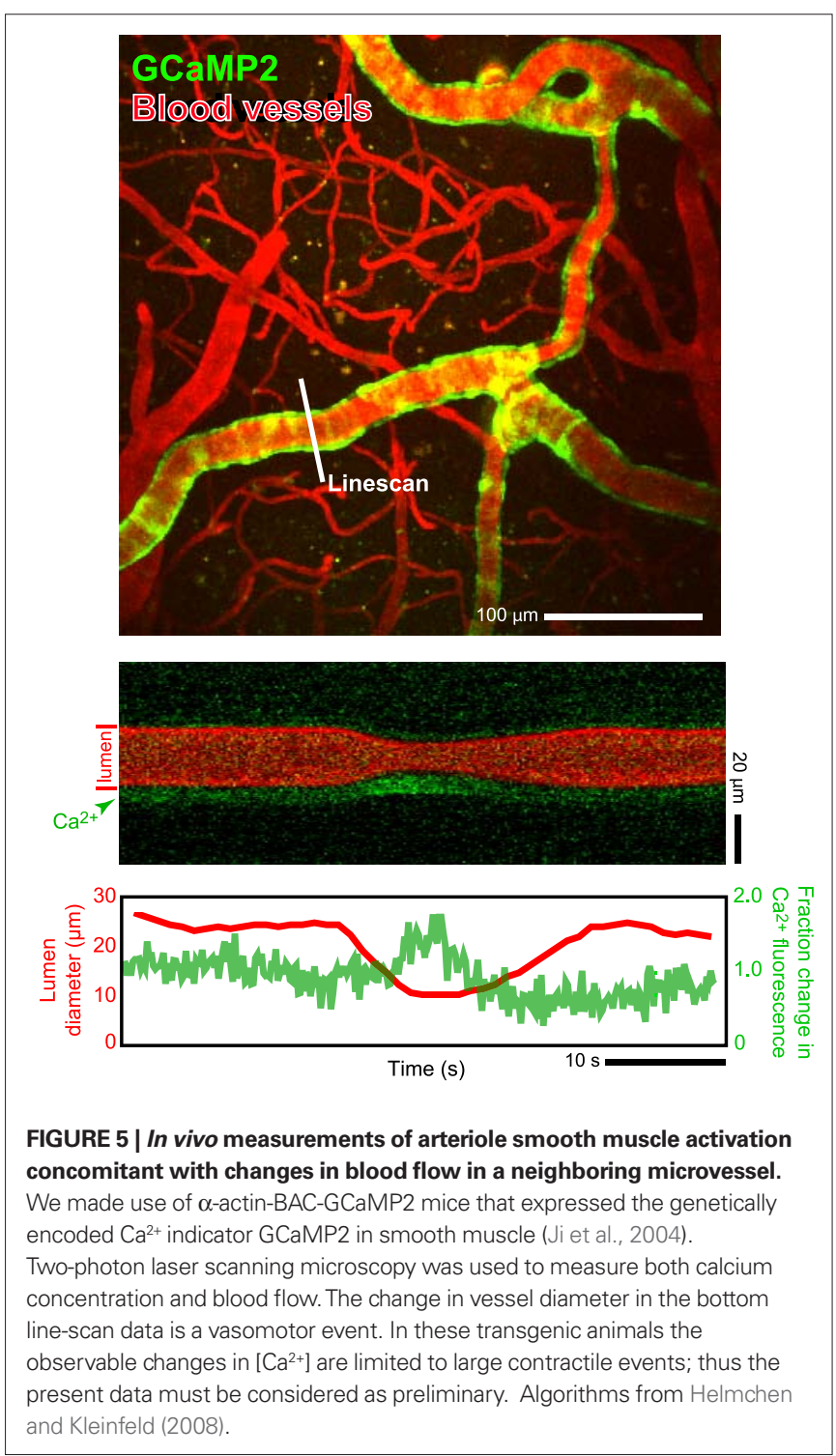


tools as they are required. One anticipated need is a calcium-clamp to control smooth muscle tension, possibly realized with caged molecules and optical indicators, as a means to fix the flow in a region and observe changes in signaling molecule concentration.

\section{EXAMPLE PROPOSED EXPERIMENT}

Somatosensory input leads to neuronal activation in ipsilateral parietal cortex as well as contralateral cortex, albeit with a reduced amplitude (Figures 7A,B). Unexpectedly, contralateral sensory input leads to net dilation of vessels, while ipsilateral input has the paradoxical effect of net constriction (Devor et al., 2008; Figure 7). One possible explanation is that contralateral input leads to rapid release of VIP while ipsilateral input preferentially excites SOM+ interneurons more slowly. One can make use of microdialysis, or for greater spatial localization an extension of CNiFER technology to form VPAC1-CNiFERs to detect vasoactive intestinal peptide and SST1-CNiFERs to detect somatostatin. We predict that the ratio of VPAC1-CNiFER to SST1-CNiFER signals will be greater for contralateral versus ipsilateral stimulation (Figure 8).

\section{PARADIGM-SHIFT TO CONSIDERING NEUROVASCULAR COUPLING IN TERMS OF SIGNALING MOLECULES}

The conventional view is that neuronal spiking leads to an increase in local metabolism, and that metabolism leads to increased oxygen extraction from the blood as well as an increase in blood speed (Fox and Raichle, 1986; Leybaert, 2005). Thus neuronal activity is

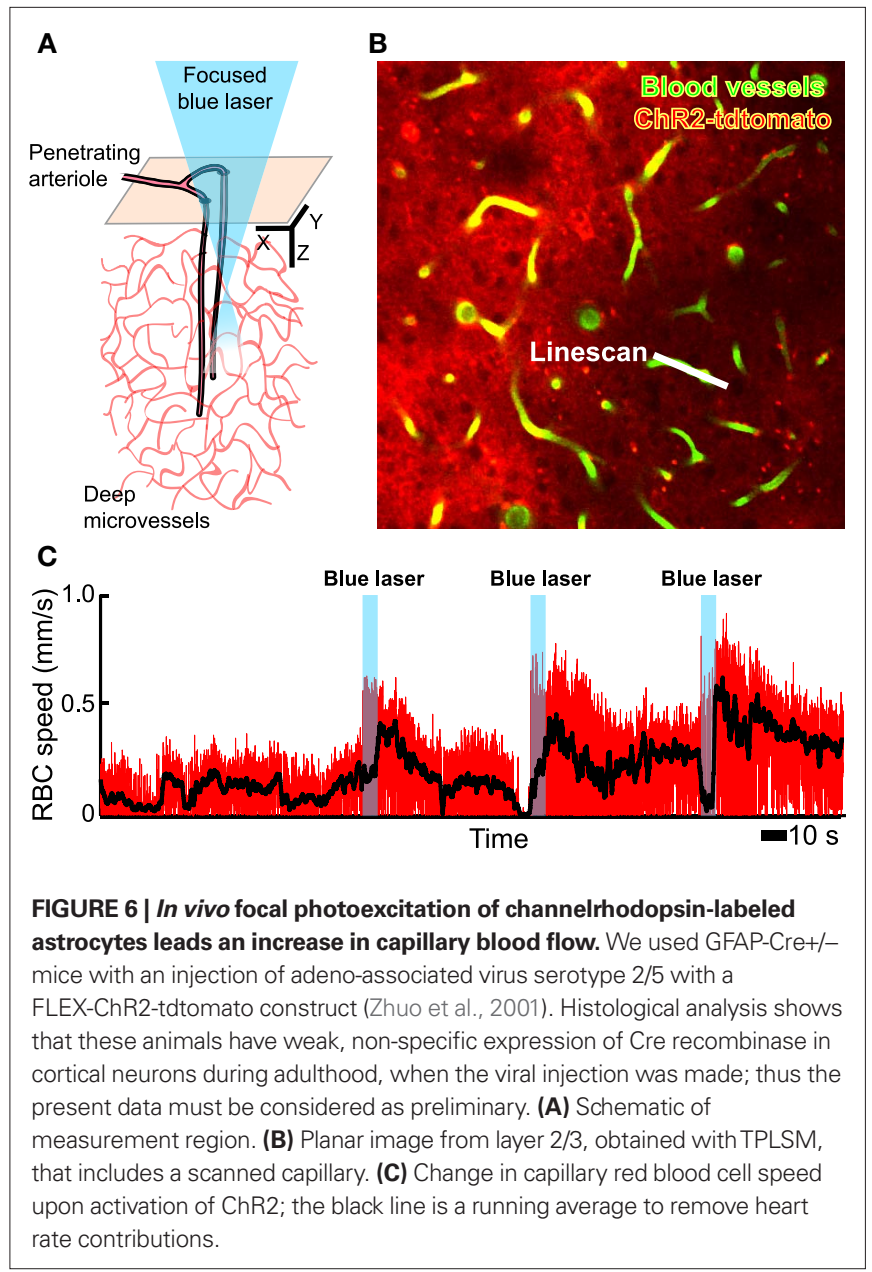

mirrored by changes in blood oxygenation. This paradigm is the accepted view for the interpretation of BOLD fMRI (Logothetis et al., 2001). But this causal relation breaks down, as shown by a multiplicity of recent experiments (Metea and Newman, 2006; Devor et al., 2008; Gordon et al., 2008; Sirotin and Das, 2008; Girouard et al., 2010; Lindauer et al., 2010; Figure 7C). We envision a model of neurovascular control that maps the activity of different neuronal subtypes to changes in vascular tone (Eqs 1 and 2). In our hypothesized paradigm, neuronal activity forms the inputs, the dynamics of the underlying signaling molecules form the internal state variables, and the vascular tone is the output state variable. This is not unlike the case of neuronal dynamics, where the input is derived from synaptic activity, the opening probabilities of channels form the internal state variables, and voltage is the output.

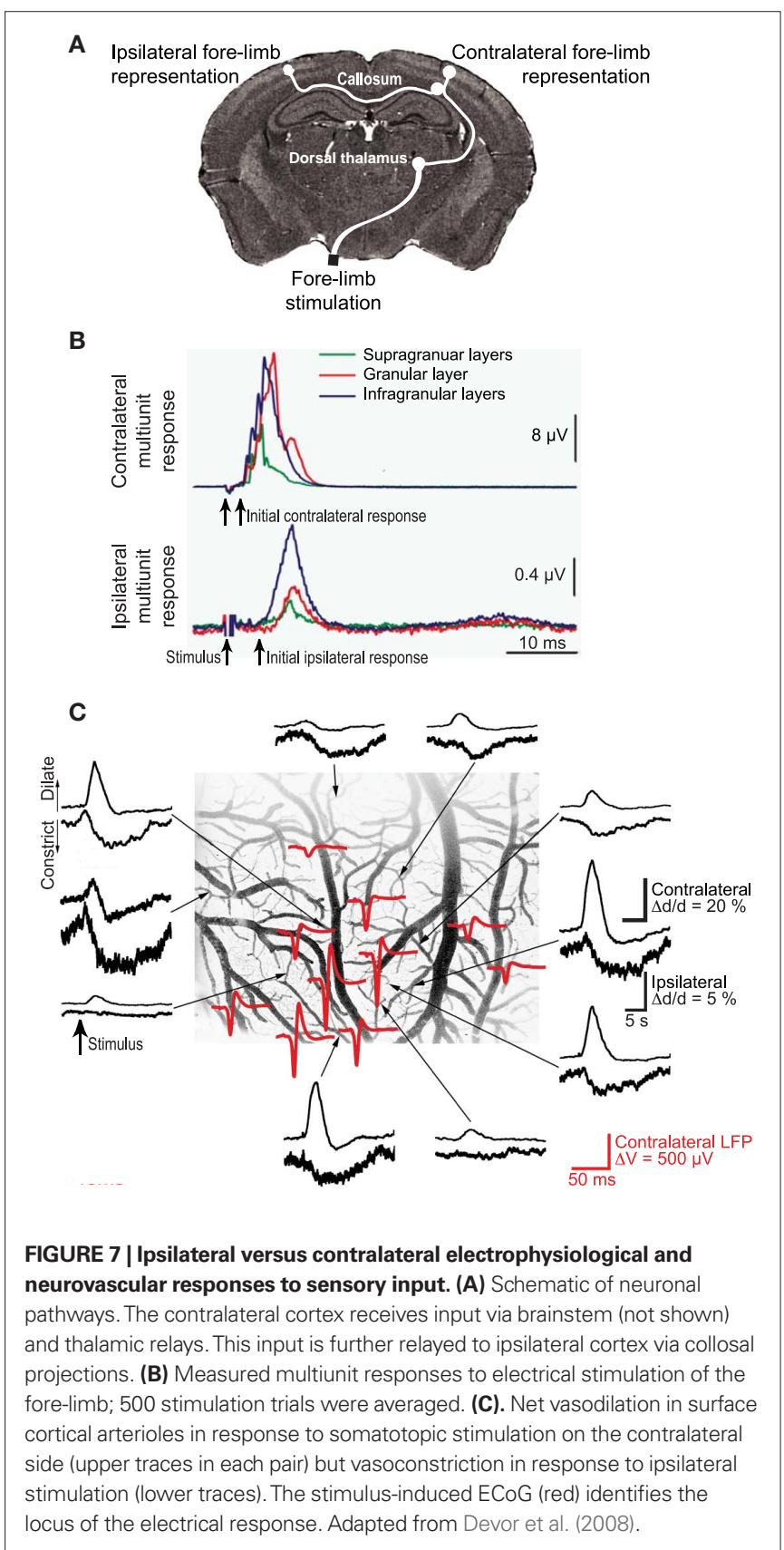




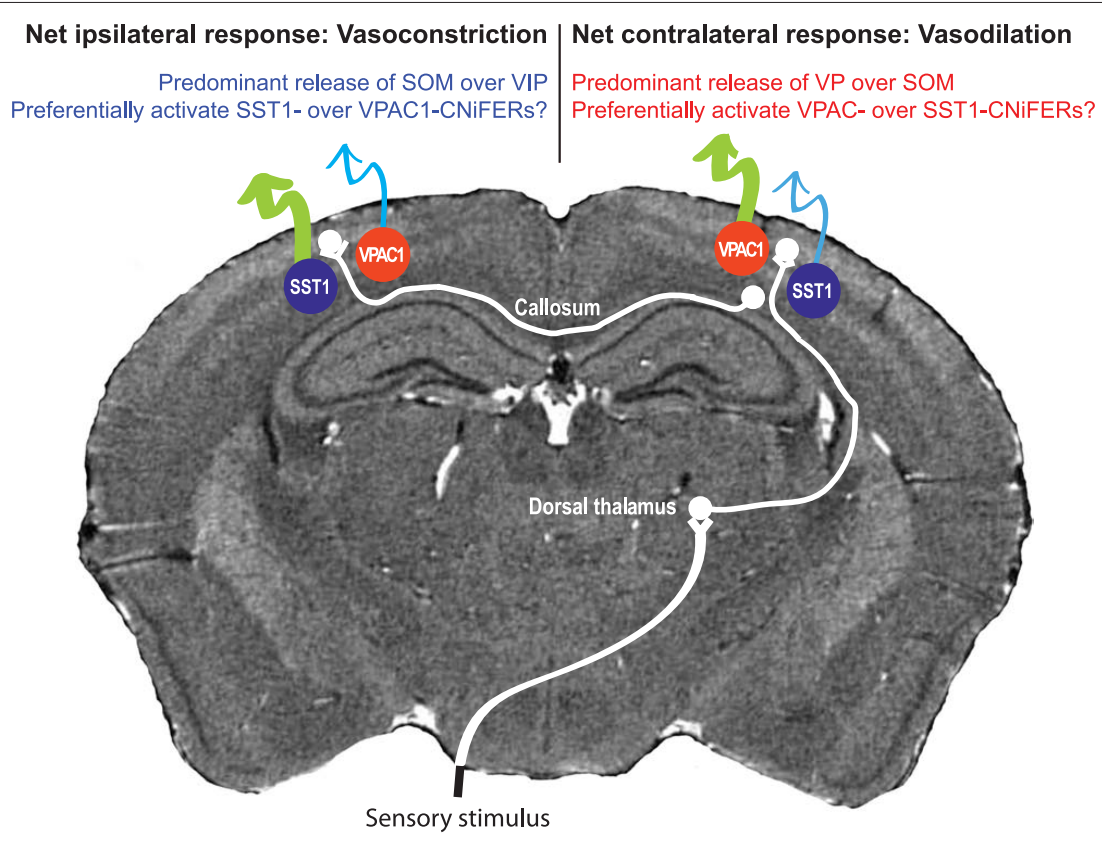

FIGURE 8 | Proposal for observing opposing vascular changes via competition of vasoactive neuropeptides. This proposal builds on the results in Figure 6, where the same sensory input leads to vasodilation at the epicenter of cortical activation in the contralateral hemisphere by vasoconstriction in the ipsilateral hemisphere. We predict that co-release of the dilator VIP dominates In the contralateral hemisphere while the constrictor SOM dominates in the ipsilateral hemisphere.

\section{ACKNOWLEDGMENTS}

We thank Costantino Iadacola, Patrick D. Lyden, and Jean Rossier for discussions and Edith Hamel for sharing artwork. This work was supported by grants from the NIH (EB003832, MH085499,
NS059832, and OD006831 to David Kleinfeld and AG029681 to Gert Cauwenberghs), and fellowships from the Israeli Science Foundation (to Pablo Blinder), Canadian Institutes of Health Research (to Andy Y. Shih), and American Heart Association (to Andy Y. Shih).

\section{REFERENCES}

Airan, R. D., Thompson, K. R., Fenno, L. E., Bernstein, H., and Deisseroth, K. (2009). Temporally precise in vivo control of intracellular signalling. Nat. Methods 458, 1025-1029.

Alexander, G. M., Rogan, S. C., Abbas, A. I., Armbruster, B. N., Pei, Y., Allen, J.A., Nonneman, R. J., Hartmann, J., Moy, S. S., Nicolelis, M.A., McNamara, J. O., and Roth, B.L. (2009). Remote control of neuronal activity in transgenic mice expressing evolved $\mathrm{G}$ protein-coupled receptors. Neuron 63, 27-39.

Arenkiel, B. R., Klein, M. E., Davison, I. G., Katz, L. C., and Ehlers, M. D. (2008). Genetic control of neuronal activity in mice conditionally expressing TRPV1. Nat. Methods 5, 299-302.

Arenkiel, B. R., Peca, J., Davison, I. G., Feliciano, C., Deisseroth, K., Augustine, G. J., Ehlers, M. D., and Feng, G. (2007). In vivo light-induced activation of neural circuitry in transgenic mice expressing channelrhodopsin-2. Neuron 54, 205-218.

Atasoy, D., Aponte, Y., Su, H. H., and Sternson, S. M. (2008). A FLEX switch targets channelrhodopsin-2 to multiple cell types for imaging and long-range circuit mapping. J. Neurosci. 28, 7025-7030.

Belliveau,J.W., Kennedy, D. N., McKinstry, R. C., Buchbinder, B. R., Weisskoff, R. M., Cohen, M.S., Vevea, J. M., Brady, T. J., and Rosen, B. R. (1991). Functional mapping of the human cortex using magnetic resonance imaging. Science 254, 716-719.

Bernard, A., Sorensen, S. A., and Lein, E. S. (2009). Shifting the paradigm: new approaches for characterizing and classifying neurons. Curr. Opin. Neurobiol. 19, 530-536.

Boyden, E. S., Zhang, F., Bamberg, E., Nagel, G., and Deisseroth, K. (2005). Millisecond-timescale, genetically targeted optical control of neural activity. Nat. Neurosci. 8, 1263-1268.

Brenner, M., Kisseberth, W. C., Su, Y., Besnard, F., and Messing, A. (1994). GFAP promotor directs astrocytespecific expression in transgenic mice. J. Neurosci. 14, 1030-1037.

Cardin, J. A., Carlén, M., Meletis, K., Knoblich, U., Zhang, F., Deisseroth, K., Tsai, L. H., and Moore, C. I. (2009). Driving fast-spiking cells induces gamma rhythm and controls sensory responses. Nat. Methods459, 663-667.
Cardin, J. A., Carlén, M., Meletis, K., Knoblich, U., Zhang, F., Deisseroth, K., Tsai, L. H., and Moore, C. I. (2010) Targeted optogenetic stimulation and recording of neurons in vivo using cell-type-specific expression of Channelrhodopsin-2. Nat. Protoc. 5, 247-254.

Cauli, B., Tong, X. K., Rancillac, A., Serluca, N., Lambolez, B., Rossier, J., and Hamel, E. (2004). Cortical GABA interneurons in neurovascular coupling: relays for subcortical vasoactive pathways. J. Neurosci. 24, 8940-8949.

Chattopadhyaya, B., Cristo, G. D., Higashiyama, H., Knott, G. W., Kuhlman, S. J., Welker, E., and Huang, Z. J. (2004). Experience and activitydependent maturation of perisomatic GABAergic innervation in primary visual cortex during a postnatal critical period. J. Neurosci. 24, 9498-9611.

Chow, B. Y., Han, X., Dobry, A. S., Qian, X., Chuong, A. S., Li, M., Henninger, M. A., Belfort, G. M., Lin, Y., Monahan, P. E., and Boyden, E. S. (2010).High-performance genetically targetable optical neural silencing by light-driven proton pumps. Nature 463, 98-102.
Cohen, Z., Molinatti, G., and Hamel, E. (1997). Astroglial and vascular interactions of noradrenaline terminals in the rat cerebral cortex. J. Cereb. Blood Flow Metab. 17, 894-904.

Coward, P., Chan, S. D., Wada, H. G., Humphries, G. M., and Conklin, B. R. (1999). Chimeric G proteins allow a high-throughput signaling assay of Gi-coupled receptors. Anal. Biochem. 270, 242-248.

Devor, A., Hillman, E. M., Tian, P., Waeber, C., Teng, I. C., Ruvinskaya, L. Shalinsky, M. H., Zhu, H., Haslinger, R. H., Narayanan, S. N., Ulbert, I., Dunn, A. K., Lo, E. H., Rosen, B. R. Dale, A. M., Kleinfeld, D., and Boas, D. A. (2008). Stimulus-induced changes in blood flow and 2-deoxyglucose uptake dissociate in ipsilateral somatosensory cortex. J. Neurosci. 28 , 14347-14357.

Drew, P. J., Blinder, P., Cauwenberghs, G., Shih, A. Y., and Kleinfeld, D. (2010) Rapid determination of particle velocity from space-time images using the Radon transform. J. Comput. Neurosci. 29, 5-11.

Drew, P. J., Duyn, J. H., Galanov, E., and Kleinfeld, D. (2008). Finding 
coherence in spontaneous oscillations. Nat. Neurosci. 11, 991-993.

Driscoll, J. D., Shih, A. Y., Drew, P. J., and Kleinfeld, D. (2011). "Quantitative two-photon imaging of blood flow in cortex," in Imaging in Neuroscience and Development, ed. R. Yuste (New York: Cold Spring Harbor Laboratory Press), in press.

Enager, P., Piilgaard, H., Offenhauser, N., Kocharyan, A., Fernandes, P., Hamel, E., and Lauritzen, M. (2008). Pathwayspecific variations in neurovascular and neurometabolic coupling in rat primary somatosensory cortex. $J$. Cereb. Blood Flow Metab. 29, 976-986.

Fahrenkrug, J., Hannibal, J., Tams, J., and Georg, B. (2000). Immunohistochemical localization of the VIP1 receptor (VPAC1R) in rat cerebral blood vessels: relation to PACAP and VIP containing nerves. J. Cereb. Blood Flow Metab. 20, 1205-1214.

Filosa, J. A., Bonev, A. D., and Nelson, M. T. (2004). Calcium dynamics in cortical astrocytes and arterioles during neurovascular coupling. Circ. Res. 95 , 73-81.

Filosa, J. A., Bonev, A. D., Straub, S. V., Meredith, A. L., Wilkerson, M. K., Aldrich, R., and Nelson, M. T. (2006). Local potassium signaling couples neuronal activity to vasodilation in the brain. Nat. Neurosci. 9, 1397-1403.

Fox, P. T., and Raichle, M. E. (1986). Focal physiological uncoupling of cerebral blood flow and oxidative metabolism during domatosensory stimulation in human subjects. Proc. Natl. Acad. Sci. U.S.A. 83, 1140-1144.

Garaschuk, O., Milos, R. I., and Konnerth, A. (2006). Targeted bulk-loading of fluorescent indicators for two-photon brain imaging in vivo. Nat. Protoc. 1 , 380-386.

Gibson, J. R., Beierlein, M., and Connors, B. W. (1999). Two networks of electrically coupled inhibitory neurons in neocortex. Nature 4, 75-79.

Girouard, H., Bonev, A. D., Hannah, R. M., Meredith, A., Aldrich, R. W., and Nelson, M. T. (2010). Astrocytic endfoot $\mathrm{Ca}_{2}{ }^{+}$and $\mathrm{BK}$ channels determine both arteriolar dilation and constriction. Proc. Natl. Acad. Sci. U.S.A. 107, 3811-3816.

Golanov, E. V., and Reis, D. J. (1996). Contribution of oxygen-sensitive neurons of the rostral ventrolateral medulla to hypoxic cerebral vasodilatation in the rat. J. Physiol. 495, 201-216.

Gordon, G. R. C., Choi, H. B., Rungta, R. L., Ellis-Davies, G.C. R., and MacVicar, B.A. (2008). Brain metabolism dictates the polarity of astrocyte control over arterioles. Nature 456, 745-750.
Gradinaru, V., Mogri, M., Thompson, K. R., Henderson, J. M., and Deisseroth, K. (2009). Optical deconstruction of Parkinsonian neural circuitry. Science 324, 354-359.

Hamel, E. (2004). Cholinergic modulation of the cortical microvascular bed. Prog. Brain Res. 145, 171-178.

Hamel,E. (2006). Perivascular nerves and the regulation of cerebrovascular tone. J. Appl. Physiol. 100, 1059-1064.

Heim, N., and Griesbeck, O. (2004). Genetically encoded indicators of cellular calcium dynamics based on troponin C and green fluorescent protein. J. Biol. Chem. 279, 14280-14286.

Helmchen, F., and Kleinfeld, D. (2008). In vivo measurements of blood flow and glial cell function with twophoton laser scanning microscopy. Methods Enzymol. 444, 231-254.

Iadecola, C., and Nedergaard, M. (2007). Glial regulation of the cerebral microvasculature. Nat. Neurosci. 10, 1369-1376.

Ji, G., Feldman, M.E., Deng, K. Y., Greene, K. S., Wilson, J., Lee, J. C., Johnston, R. C., Rishniw, M., Tallini, Y., Zhang, J., Wier, W. G., Blaustein, M. P., Xin, H. B., Nakai, J., and Kotlikoff, M. I. (2004). Ca2+-sensing transgenic mice: postsynaptic signaling in smooth muscle. J. Biol. Chem. 279, 21461-21468.

Jones, M., Devonshire, I. M., Berwick, J., Martin, C., Redgrave, P., and Mayhew, J. (2008). Altered neurovascular coupling during information-processing states. Eur. J. Neurosci. 27, 2758-2772.

Kawaguchi, Y. (2001). Distinct firing patterns of neuronal subtypes in cortical synchronized activities. J. Neurosci. 21 , 7261-7272.

Kocharyan, A., Fernandes, P., Tong, X. K., Vaucher, E., and Hamel, E. (2008). Specific subtypes of cortical GABA interneurons contribute to the neurovascular coupling response to basal forebrain stimulation. J. Cereb. Blood Flow Metab. 28, 221-231.

Kövari, E., Gold, G., Herrmann, F. R., Canuto, A., Hof, P. R., Bouras, C., and Giannakopoulos, P. (2007). Cortical microinfarcts and demyelination affect cognition in cases at high risk for dementia. Neurology 66, 927-931.

LeDoux, J.E., Thompson, M. E., Iadecola, C., Tucker, L.W., and Reis, D. J. (1983). Local cerebral blood flow increases during auditory and emotional processing in the conscious rat. Science $221,573-578$.

Leybaert, L. (2005). Neurobarrier coupling in the brain: a partner of neurovascular and neurometabolic coupling? J. Cereb. Blood Flow Metab. 25, 2-16. Lindauer, U., Leithner, C., Kaasch, H., Rohrer, B., Foddis, M., Füchtemeier
M., Offenhauser, N., Steinbrink, J., Royl, G., Kohl-Bareis, M., and Dirnagl, U. (2010). Neurovascular coupling in rat brain operates independent of hemoglobin deoxygenation. J. Cereb. Blood Flow Metab. 30, 757-768.

Logothetis, N. K., Pauls, J., Augath, M., Trinath, T., and Oeltermann, A. (2001). Neurophysiological investigation of the basis of the fMRI signal. Nature 412, 150-157.

Luo, L., Callaway, E. M., and Svoboda, K. (2008). Genetic dissection of neural circuits. Neuron 57, 634-660.

Ma, Y., Hu, H., Berrebi, A. S., Mathers, P. H., and Agmon, A. (2006). Distinct subtypes of somatostatin-containing neocortical interneurons revealed in transgenic mice. J. Neurosci. 26, 5069-5082.

Madisen, L., Zwingman, T. A., Sunkin, S. M., Oh, S. W., Zariwala, H. A., Gu, H., Ng, L. L., Palmiter, R. D., Hawrylycz, M. J., Jones, A. R., Lein, E. S., and Zeng, H. (2010). A robust and high-throughput Cre reporting and characterization system for the whole mouse brain. Nat. Neurosci. 13, 133-140.

Mallo, M. (2006). Controlled gene activation and inactivation in the mouse. Front. Biosci. 11, 313-327.

Mank, M., Santos, A. F., Direnberger, S., Mrsic-Flogel, T. D., Hofer, S. B., Stein, V., Hendel, T., Reiff, D. F., Levelt, C. Borst, A., Bonhoeffer, T., Hübener, M. and Griesbeck, O. (2008). A genetically encoded calcium indicator for chronic in vivo two-photon imaging. Nat Methods 5, 805-811.

Metea, M. R., and Newman, E. A. (2006) Glial cells dilate and constrict blood vessels: a mechanism of neurovascular coupling. J. Neurosci. 26 , 2862-2870.

Mulligan, S. J., and MacVicar, B. A. (2004). Calcium transients in astrocyte endfeet cause cerebrovascular constrictions. Nature 431, 195-199.

Nguyen, Q.-T., Schroeder, L. F., Mank, M., Muller, A., Taylor, P.W., Griesbeck, O. and Kleinfeld, D. (2010). An in vivo biosensor for neurotransmitter release and in situ receptor activity. Nat Neurosci. 13, 127-132.

Niessing, J., Ebisch, B., Schmidt, K. E. Niessing, M., Singer, W., and Galuske, R. A. (2005). Hemodynamic signals correlate tightly with synchronized gamma oscillations. Science 309 , 948-951.

Nolte, C., Matyash, M., Pivneva, T., Schipke, C. G., Ohlemeyer, C., Hanisch, U. K., Kirchhoff, F., and Kettenmann, H. (2001). GFAP promoter-controlled EGFP-expressing transgenic mice: a tool to visualize astrocytes and astrogliosis in living brain tissue. Glia 33, 72-86.
Ogawa, S., Tank, D. W., Menon, R., Ellermann, J. M., Kim, S.-G., Merkle, H., and Ugurbil, K. (1992). Intrinsic signal changes accompanying sensory stimulation: functional brain mapping with magnetic resonance imaging. Proc. Natl. Acad. Sci. U.S.A. 89, 5951-5955.

Oliva, A. A. Jr., Jiang, M., Lam, T., Smith, T. L., and Swann, J. W. (2000). Novel hippocampal interneuronal subtypes identified using transgenic mice that express green fluorescent protein in GABAergic interneurons. J. Neurosci. 20, 3354-3368.

Paulson, O. B., Strandgaard, S., and Edvinsson, L. (1990). Cerebral autoregulation. Cerebrovasc. Brain Metab. Rev. 2, 161-192.

Sakadzić, S., Roussakis, E., Yaseen, M. A., Mandeville, E. T., Srinivasan, V.J., Arai, K., Ruvinskaya, S., Devor, A., Lo, E. H., Vinogradov, S. A., and Boas, D. A. (2010). Two-photon high-resolution measurement of partial pressure of oxygen in cerebral vasculature and tissue. Nat. Methods 7, 755-759.

Shaner, N. C., Campbell, R. E., Steinbach, P. A., Giepmans, B. N., Palmer, A. E., and Tsien, R. Y. (2004). Improved monomeric red, orange and yellow fluorescent proteins derived from Discosoma sp. red fluorescent protein. Nat. Biotechnol. 22, 1567-1572.

Shmueli, K., van Gelderen, P., de Zwart, J. A., Horovitz, S. G., Fukunaga, M., Jansma, J. M., and Duyn, J. H. (2007). Low-frequency fluctuations in the cardiac rate as a source of variance in the resting-state fMRI BOLD signal. Neuroimage 38, 306-320.

Sirotin, Y. B., and Das, A. (2008). Anticipatory haemodynamic signals in sensory cortex not predicted by local neuronal activity. Nature 457, 475-479.

Sohal, V. S., Zhang, F., Yizhar, O., and Deisseroth, K. (2009). Parvalbumin neurons and gamma rhythms enhance cortical circuit performance. Nature 459, 698-702.

Svoboda, K., Denk, W., Kleinfeld, D., and Tank, D. W. (1997). In vivo dendritic calcium dynamics in neocortical pyramidal neurons. Nature 385, 161-165.

Takano, T., Tian, G. F., Peng, W., Lou, N., Libionka, W., Han, X., and Nedergaard, M. (2006). Astrocytemediated control of cerebral blood flow. Nat. Neurosci. 9, 260-267.

Tamamaki, N., Yanagawa, T., Tomioka, R., Miyazaki, J., Obata, K., and Kaneko, T. (2003). Green fluorescence protein expression and colocalization with calretinin, parvalbumin, and somatostatin in the GAD67-GFP knock-in mouse. J. Comp. Neurol. 40, 60-79. 
Tian, L., Hires, S. A., Mao, T., Huber, D., Chiappe, M. E., Chalasani, S. H., Petreanu, L.,Akerboom, J., McKinney, S. A., Schreiter, E. R., Bargmann, C. I., Jayaraman, V., Svoboda, K., and Looger, L. L. (2009). Imaging neural activity in worms, flies and mice with improved GCaMP calcium indicators. Nat. Methods 6, 875-881.

Tsai, P. S., Friedman, B., Ifarraguerri, A. I., Thompson, B. D., Lev-Ram, V., Schaffer, C. B., Xiong, Q., Tsien, R. Y., Squier, J. A., and Kleinfeld, D. (2003). All-optical histology using ultrashort laser pulses. Neuron 39, 27-41.

Tsai, P. S., Kaufhold, J., Blinder, P., Friedman, B., Drew, P., Karten, H. J., Lyden, P. D., and Kleinfeld, D. (2009). Correlations of neuronal and microvascular densities in murine cortex revealed by direct counting and colocalization of cell nuclei and microvessels. J. Neurosci. 18, 14553-14570.

Tsien, J. Z., Chen, D. F., Gerber, D., Tom, C., Mercer, E. H., Anderson, D. J., Mayford, M., Kandel, E. R., and Tonegawa, S. (1996). Subregion- and cell type-restricted gene knockout in mouse brain. Cell 87, 1317-1326.
Tsien, R. Y. (1998). The green fluorescent protein. Annu. Rev. Biochem. 67, 509-544.

Wallace, D. J., Borgloh, S. M. Z. A., Astori, S., Yang, Y., Bausen, M., Kügler, S., Palmer, A. E., Tsien, R. Y., Sprengel, R., Kerr, J. N., Denk, W., and Hasan, M. T. (2008). Single-spike detection in vitro and in vivo with a genetic $\mathrm{Ca} 2+$ sensor. Nat. Methods 5, 797-804.

Wang, X., Lou, N., Xu, Q., Tian, G. F., Peng, W. G., Han, X., Kang, J., Takano, T., and Nedergaard,M. (2006). Astrocytic Ca2 ${ }^{+}$ signaling evoked by sensory stimulation in vivo. Nat. Neurosci. 9, 816-823.

Weaver, A. K., Bomben, V. C., and Sontheimer, H. (2006). Expression and function of calcium-activated potassium channels in human glioma cells. Glia 54, 223-233.

Wise, R. G., Ide, K., Poulin, M.J., and Tracey, I. (2004). Resting fluctuations in arterial carbon dioxide induce significant low frequency variations in BOLD signal. Neuroimage 21, 1652-1664.

Wulff, P., Ponomarenko, A. A., Bartos, M., Korotkova, T. M., Fuchs, E. C., Bahner, F., Both, M., Tort, A. B. L., Kopell, N. J., Wisden, W., and Monyer, H. (2008). Hippocampal theta rhythm and its coupling with gamma oscillations require fast inhibition onto paralbumin-positive interneuron. Proc. Natl. Acad. Sci.U.S.A. 106, 3561-3566.

Xin, H. B., Deng, K. Y., Rishniw, M., Ji, G., and Kotlikoff, M. I. (2002a). Smooth muscle expression of Cre recombinase and eGFP in transgenic mice. Physiol. Genomics 10, 211-219.

Xin, H. B., Deng, K. Y., Rishniw, M., Ji, G., and Kotlikoff, M. I. (2002b). Smooth muscle expression of Cre recombinase and eGFP in transgenic mice. Physiol. Genomics 10, 211-215.

Zhang, F., Wang, L.-P., Brauner, M., Liewald, J. F., Ka, K., Watzke, N., Wood, P. G., Bamberg, E., Nagel, G., Gottschalk, A., and Deisseroth, K. (2007). Multimodal fast optical interrogation of neural circuitry. Nature 446, 633-641.

Zhuo, L., Theis, M., Alvarez-Maya, I., Brenner, M., Willecke, K., and Messing, A. (2001). hGFAP-cre transgenic mice for the manipulation of glial and neuronal function in vivo. Genesis 31, 85-94.

Zonta, M., Angulo, M. C., Gobbo, S., Rosengarten, B., Hossmann, K. A.,
Pozzan, T., and Carmignoto, G. (2003). Neuron-to-astrocyte signaling is central to the dynamic control of brain microcirculation. Nat. Neurosci. 6, 43-50.

Conflict of Interest Statement: The authors declare that the research was conducted in the absence of any commercial or financial relationships that could be construed as a potential conflict of interest.

Received: 08 March 2010; paper pending published: 08 March 2010; accepted: 11 April 2011; published online: 25 April 2011. Citation: Kleinfeld D, Blinder P, Drew PJ, Driscoll JD, Muller A, Tsai PS and Shih AY (2011) A guide to delineate the logic of neurovascular signaling in the brain. Front. Neuroenerg. 3:1. doi: 10.3389/ fnene.2011.00001

Copyright $\odot 2011$ Kleinfeld, Blinder, Drew, Driscoll, Muller, Tsai and Shih. This is an open-access article subject to a nonexclusive license between the authors and Frontiers Media SA, which permits use, distribution and reproduction in other forums, provided the original authors and source are credited and other Frontiers conditions are complied with. 